\title{
MYXOPAPILLARY EPENDYMOMA OF THE SPINAL CORD IN ADULTS: A REPORT OF PERSONAL SERIES AND REVIEW OF LITERATURE
}

\author{
Ibrahim Omerhodžić ${ }^{1}$, Mirza Pojskiće ${ }^{2,3}$, Krešimir Rotim $^{3-5}$, Bruno Splavski $^{3-6}$, \\ Lukas Rasulić 7 and Kenan I. Arnautovic ${ }^{8,9}$ \\ ${ }^{1}$ Department of Neurosurgery, Sarajevo University Clinical Center, Sarajevo, Bosnia and Herzegovina; \\ ${ }^{2}$ Department of Neurosurgery, University of Marburg, Marburg, Germany; \\ ${ }^{3}$ Josip Juraj Strossmayer University of Osijek, Faculty of Medicine, Osijek, Croatia; \\ ${ }^{4}$ University of Applied Health Sciences, Zagreb, Croatia; \\ ${ }^{5}$ Department of Neurosurgery, Sestre milosrdnice University Hospital Centre, Zagreb, Croatia; \\ ${ }^{6}$ Josip Juraj Strossmayer University of Osijek, School of Dental Medicine and Health, Osijek, Croatia; \\ ${ }^{7}$ Department of Neurosurgery, Clinical Center of Serbia, Belgrade, Serbia; \\ ${ }^{8}$ Semmes Murphey Neurologic \& Spine Institute, Memphis, TN, United States; \\ ${ }^{9}$ Department of Neurosurgery, University of Tennessee Health Science Center, Memphis, TN, United States
}

\begin{abstract}
SUMMARY - Myxopapillary ependymomas (MPE) of the spinal cord are slow-growing benign tumors most frequently found in adults between 30 and 50 years of age. They arise from the ependyma of the filum terminale and are located in the area of the medullary conus and cauda. The recommended treatment option is gross total resection, while patients undergoing subtotal resection usually require radiotherapy. Complete resection without capsular violation can be curative and is often accomplished by simple resection of the filum above and below the tumor mass. Nevertheless, dissemination and distant treatment failure may occur in approximately $30 \%$ of the cases. In this paper, we propose an original MPE classification, which is based upon our personal series report concerned with tumor location and its correlation with the extent of resection. We also provide literature review, discussing surgical technique, tumor recurrence rate and dissemination, and adjuvant treatment. In conclusion, our findings suggest that MPE management based on the proposed 5-type tumor classification is favorable when total surgical resection is performed in carefully selected patients. Yet, further studies on a much broader model is obligatory to confirm this.
\end{abstract}

Key words: Myxopapillary ependymoma; Gross total resection; Surgical technique; Tumor classification

\section{Introduction}

Spinal cord myxopapillary ependymoma (MPE) derives from the filum terminale ${ }^{1}$, representing the most common tumor of the medullary conus and ac-

Correspondence to: Kenan Arnautovic, MD, PhD, 6325 Humphreys Blvd, Memphis, TN 38120, USA

E-mail: karnautovic@semmes-murphey.com

Received April 24, 2020, accepted May 26, 2020 counts for nearly $13 \%$ of all ependymomas ${ }^{2-4}$. According to the World Health Organization (WHO) classification $^{5,6}, \mathrm{MPE}$ is a slow-growing grade I tumor, which is most often found in adults aged $30-50$ years $^{7}$. Although such a tumor is mainly situated in the lumbar spine just below the medullary conus, it may also spread to the thoracic spine, and sacrum ${ }^{8}$. Some of these tumors may become aggressive in spite of their benign histopathology, and they may metastasize 


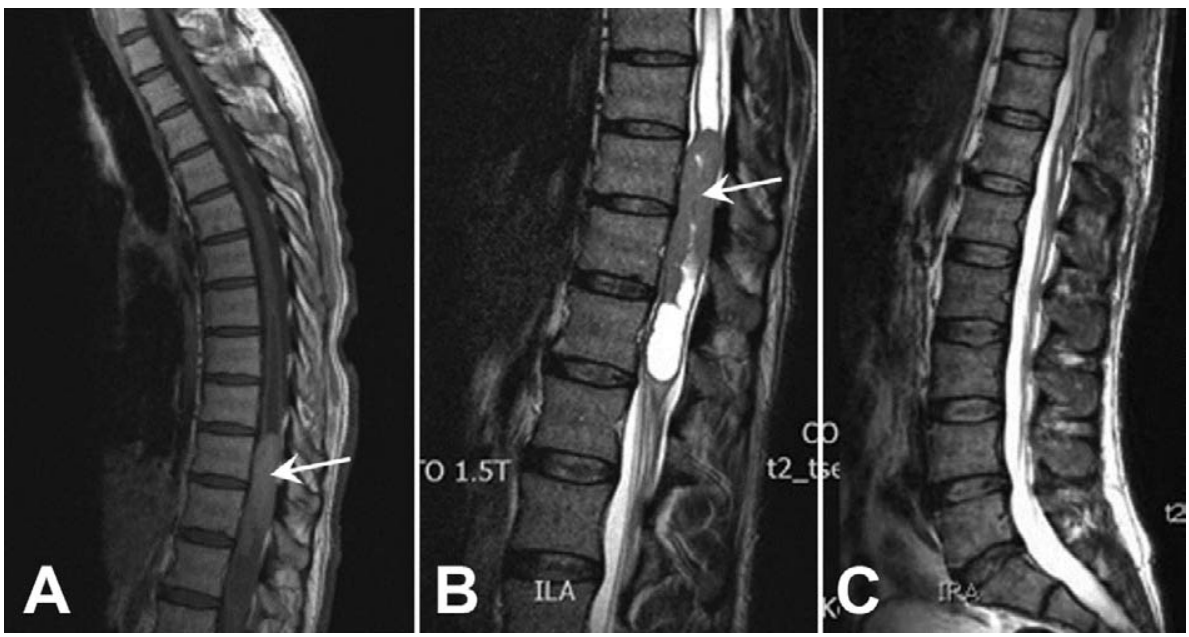

Fig. 1. Preoperative sagittal post-contrast T1-weighted MRI of the spine showing a cystic contrast-enhancing tumor at medullary conus (L1-2) level (arrow) with syringomyelia at T10-12 level (a) and sagittal T2-weighted MRI visualizing the cyst and syringomyelia (arrow) better (b). Postoperative sagittal T2-weighted $M R I$ revealing complete tumor resection with syringomyelia resolution (c).
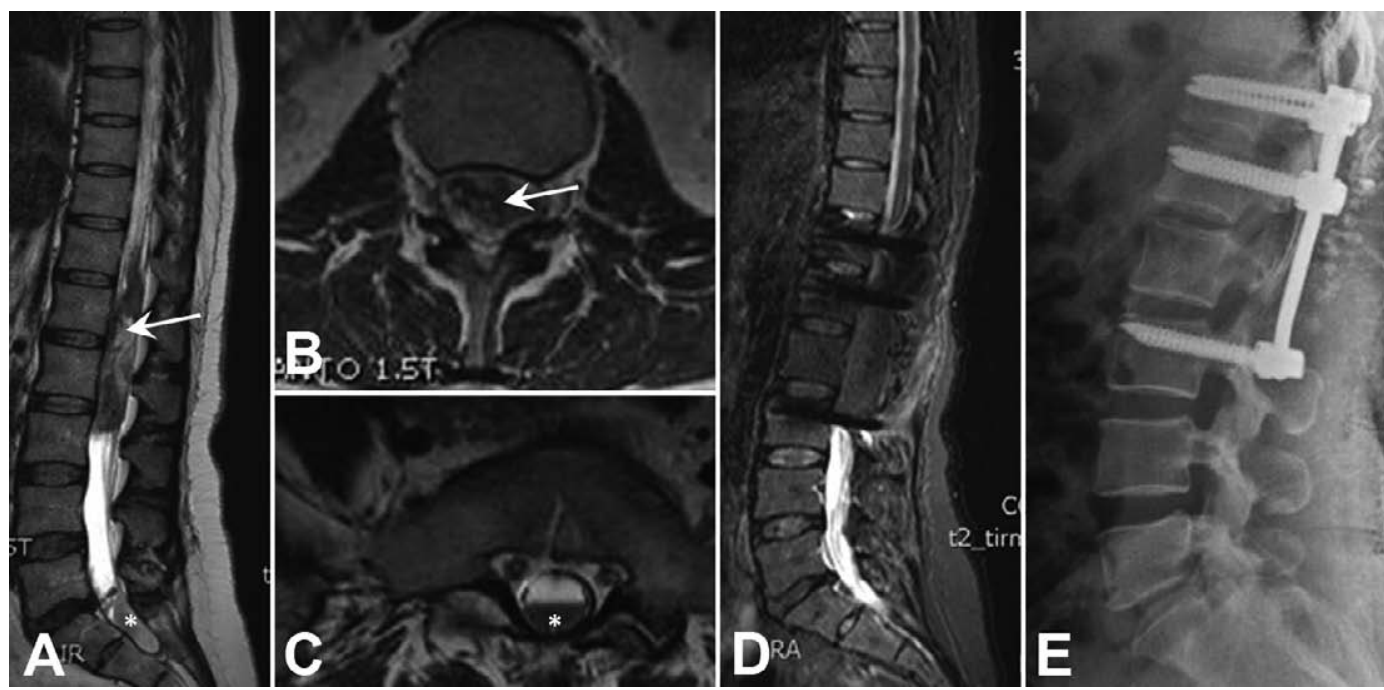

Fig. 2. Preoperative sagittal T2-weighted spinal MRI revealing spinal cord cystic tumor with intratumoral hemorrhage at L1-L3 level (arrow), and subdural hematoma at S1 level (asterisk) (a). Axial T2-weighted MRI demonstrating the tumor cyst of the vertebral canal ventral part at L1 level (arrow) (b) and subdural hematoma of the dorsal part of the canal at S1 level (asterisk) (c). Postoperative sagittal T2-weighted MRI confirming complete tumor resection, hematoma evacuation, and spinal T12-L3 stabilization (d,e).

along the neural axis to distant cranial and spinal locations, or to local spots after surgery ${ }^{1,9}$. Therefore, gross total tumor resection, accompanied by intraoperative neuromonitoring, remains the best surgical management option available ${ }^{9-11}$, while patients undergoing partial (subtotal) resection typically require adjuvant high-dose radiotherapy ${ }^{12,13}$. Complete tumor removal without iatrogenic capsular damage followed by simple resection of the filum above and below the tumor mass is always beneficial, but it may be difficult to ac- 

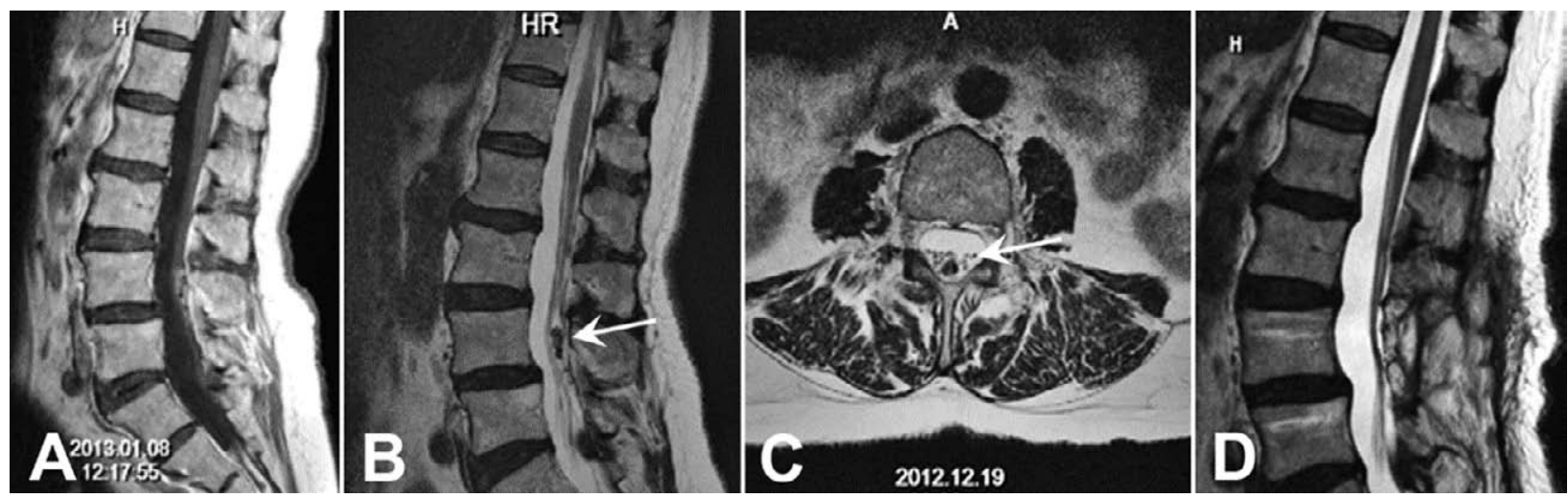

Fig. 3. Preoperative sagittal contrast-enhanced T1-weighted spinal MRI demonstrating an intradural-extramedullary tumor mass at L4 level (a) confined to filum terminale and adherent to the nerve roots (a). Preoperative T2-weighted sagittal (arrow) (b) and axial (arrow) MRI scans (c) visualizing the tumor confined to the filum terminale and adherent to the nerve roots. Postoperative sagittal T2-weighted MRI showing gross total tumor resection (d).

complish. When rupture of the tumor capsule occurs during surgery, brain and whole spine adjuvant radiotherapy is suggested to prevent local recurrence and cerebrospinal fluid (CSF) dissemination ${ }^{14}$. Preservation of sacrococcygeal nerve roots is vital to diminish the incidence of postoperative urinary dysfunction ${ }^{15}$. Nevertheless, neural axis dissemination, distant treatment failure, and tumor relapse may occur in one-third of patients ${ }^{13}$.

Herein, we present a 7 -case personal series report and propose an original anatomical and surgical MPE classification grounded on tumor location and its correlation with the extent of resection ${ }^{16}$. We also provide a literature review, discussing surgical technique, tumor recurrence rate and dissemination, and adjuvant treatment.

\section{Case Series Report}

\section{Case 1}

A 45-year-old female was admitted to the hospital due to minor lower-limb motor weakness and urinary retention. A cystic contrast-enhancing tumor at L1-2 level (arrow) with syringomyelia at T10-12 level was identified on preoperative sagittal post-contrast T1weighted spinal magnetic resonance imaging (MRI) (Fig. 1a). The cyst and syringomyelia (arrow) were well visualized on sagittal T2-weighted MRI (Fig. 1b). According to our classification, the tumor was determined to be type IV B MPE (involving the entire medullary conus with cystic compartment and signs of syringomyelia in the upper part of the cord). Postoperative sagittal T2-weighted MRI of the spine revealed complete tumor resection with syringomyelia resolution (Fig. 1c) resulting in full neurological recovery.

\section{Case 2}

A 43-year-old female presented with acute urinary retention and initial paraparesis. A spinal cord cystic tumor with intratumoral hemorrhage at L1-L3 level (arrow), and subdural hematoma at S1 level (asterisk) were visualized on sagittal T2-weighted MRI of the lumbar spine (Fig. 2a). Axial T2-weighted MRI demonstrated tumor cyst of the vertebral canal ventral part at L1 level (arrow) (Fig. 2b), and subdural hematoma of the dorsal part of the canal at S1 level (asterisk) (Fig. 2c). The tumor was also classified as type IV B MPE (involving the entire medullary conus with cystic compartment hemorrhage). Complete tumor resection, hematoma evacuation, and spinal T12-L3 stabilization with transpedicular screws and rods were accomplished successfully, which was confirmed by postoperative sagittal T2-weighted MRI (Fig. 2d,e) and resulted in full patient recovery.

\section{Case 3}

A 72-year-old female complained of low back and bilateral leg pain without any neurological deficit. Preoperative sagittal contrast-enhanced T1-weighted spinal MRI demonstrated an intradural-extramedullary 


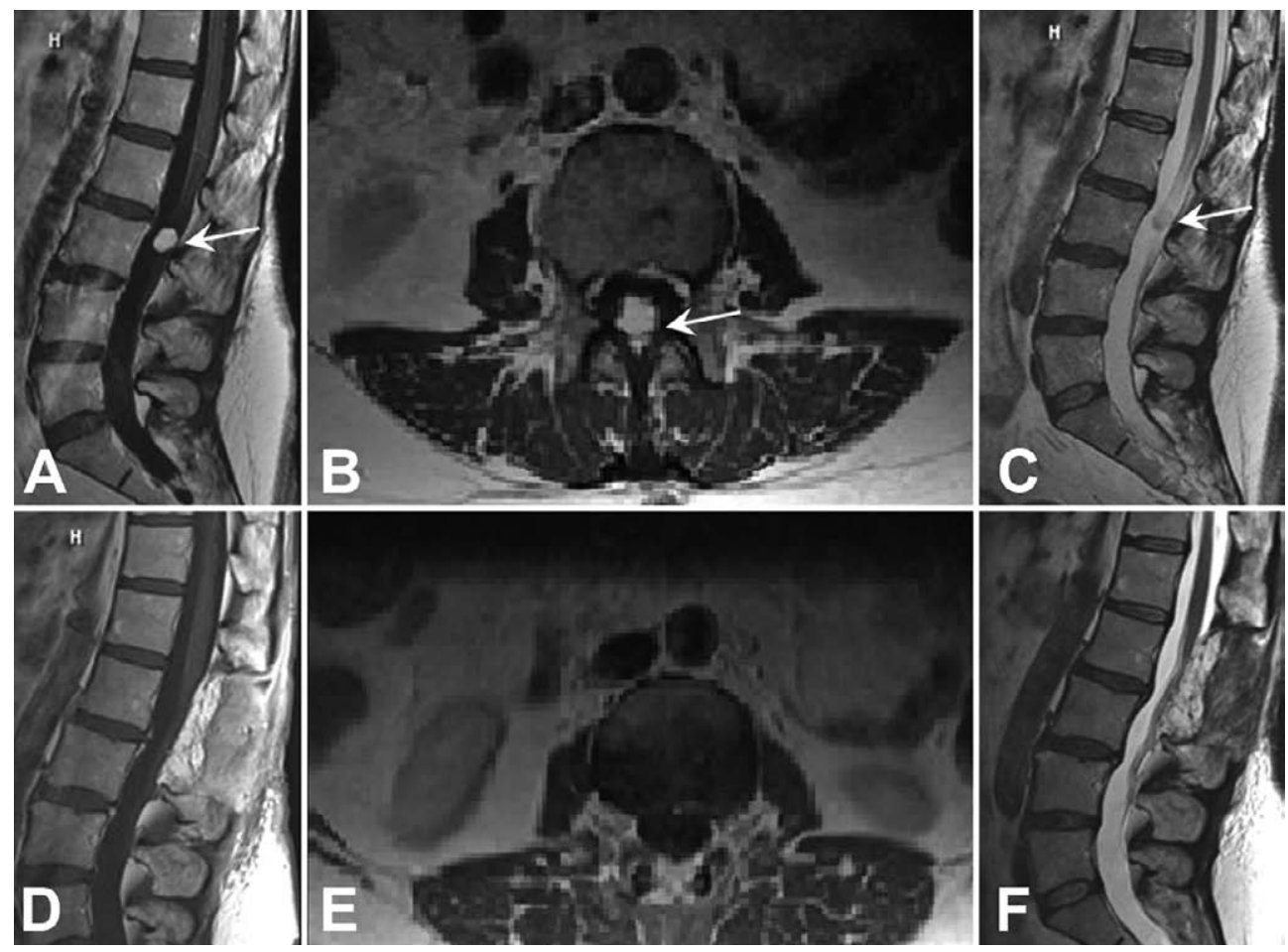

Fig. 4. Preoperative sagittal post-contrast T1-weighted MRI of the lumbar spine showing an enhancing solid tumor at L3 level with engrossment of filum terminale and cauda equina (a), also shown on post-contrast axial T1-weighted (b) and sagittal T2-weighted MRI (c) (arrows). Postoperative post-contrast T1-weighted sagittal (d), axial (e) and sagittal T2-weighted $M R I(f)$ confirming total tumor resection.

tumor mass at L4 level (Fig. 3a). The tumor, which was confined to the filum terminale and adherent to the nerve roots, was also visible on preoperative T2weighted sagittal (arrow) (Fig. 3b) and axial (arrow) (Fig. 3c) MRI scans. The tumor was classified as type I B MPE (extramedullary conus with lumbar nerve root and filum involvement). Postoperative sagittal T2weighted MRI demonstrated gross total tumor resection (Fig. 3d). The patient reported no low back and leg pain following surgery.

\section{Case 4}

A 56-year-old female presented with low back pain, lower limb numbness, and voiding difficulties. Preoperative sagittal post-contrast T1-weighted MRI of the lumbar spine showed an enhancing solid tumor at L3 level affecting filum terminale and cauda equina (Fig. 4a), which was also shown on post-contrast axial T1-weighted (Fig. 4b) and sagittal T2-weighted (Fig. 4c) MRI scans (arrows). The tumor was classified as type I B MPE (extramedullary conus with lumbar nerve root and filum involvement). Postoperative postcontrast T1-weighted sagittal (Fig. 4d), axial (Fig. 4e), as well as sagittal T2-weighted MRI (Fig. 4f) demonstrated total tumor resection resulting in complete neurological recovery.

\section{Case 5}

A 47-year-old female presented with paraparesis, L2 level sensory loss, and bowel incontinence. Preoperative post-contrast sagittal T2-weighted (Fig. 5a) and T1-weighted (Fig. 5b) lumbar spine MRI demonstrated a solid tumor mass at L3 level (arrows). The tumor was classified as type I B MPE (extramedullary conus with lumbar nerve root and filum involvement). Postoperative sagittal T2-weighted MRI confirmed complete tumor resection (Fig. 5c). The patient remained neurologically intact following surgery. 


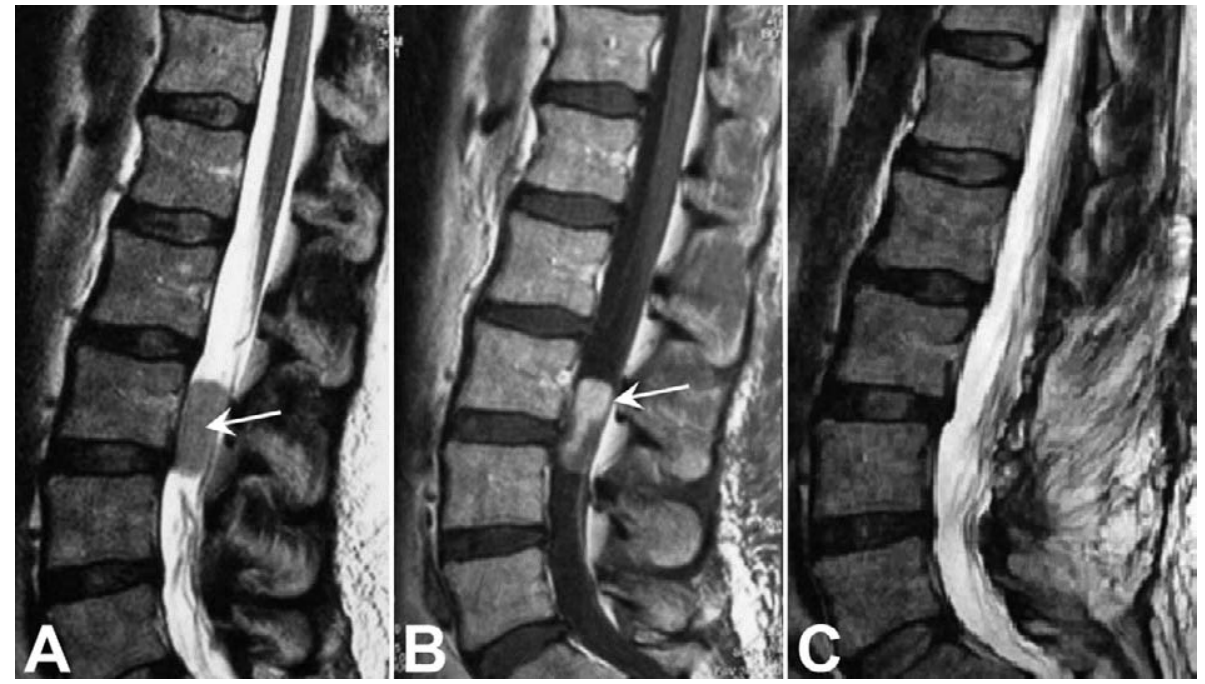

Fig. 5. Preoperative post-contrast sagittal T2-weighted (a) and T1-weighted (b) lumbar spine MRI demonstrating a solid tumor mass at L3 level (arrows). Postoperative sagittal T2-weighted MRI confirming complete tumor resection (c).
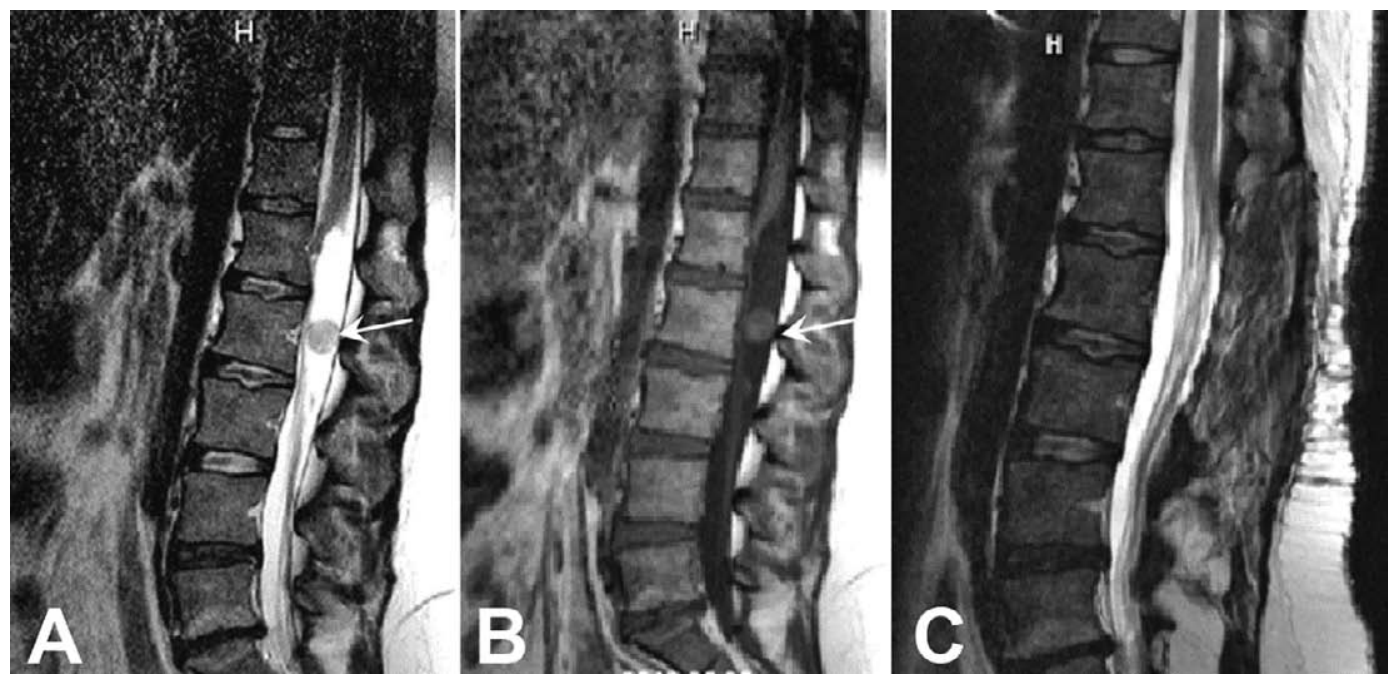

Fig. 6. Preoperative post-contrast sagittal T2-weigted (a) and T1-weighted (b) lumbar MRI revealing a large cystic tumor at $L 2$ level with hydromyelia and involvement of medullary conus. Postoperative sagittal T2-weighted MRI confirming complete tumor resection with cyst drainage and hydromyelia resolution (c).

\section{Case 6}

A 35-year-old male presented with severe low back pain and urinary retention. Preoperative post-contrast sagittal T2-weigted (Fig. 6a) and T1-weighted (Fig. 6b) lumbar MRI demonstrated a large cystic tumor at L2 level with hydromyelia and involvement of the medullary conus. The tumor was classified as type IV B
MPE (involving the entire medullary conus with cystic compartment and signs of hydromyelia in the upper part of the cord). Postoperative sagittal T2-weighted MRI showed complete tumor resection with cyst drainage and hydromyelia resolution (Fig. 6c). Following surgery, the patient reported no urinary retention or other neurological deficit. 


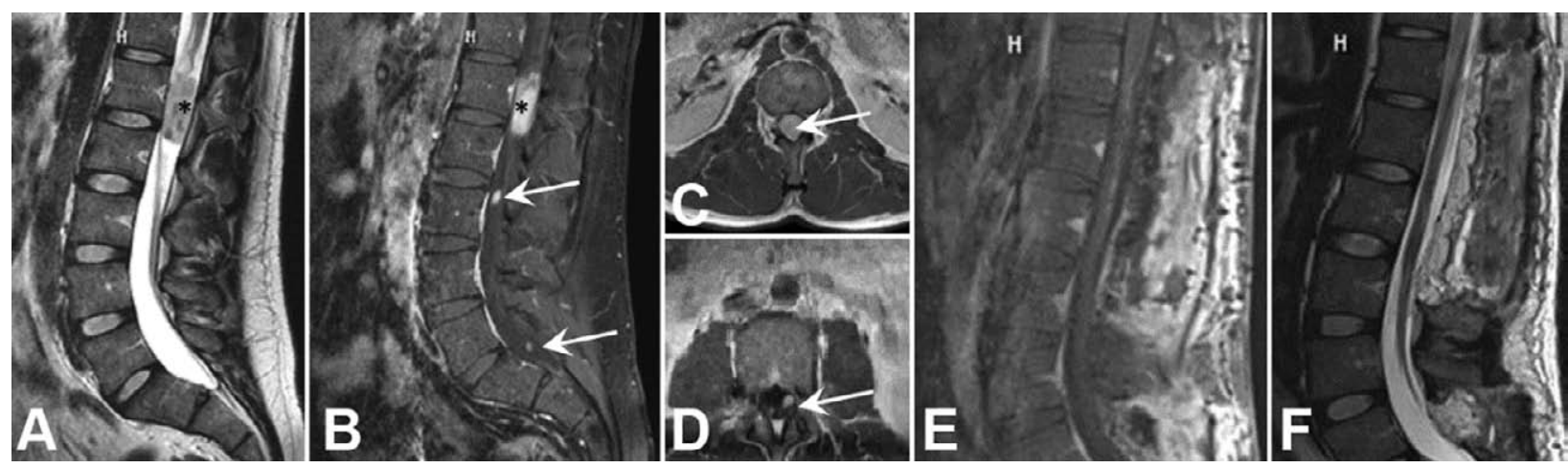

Fig. 7. Preoperative post-contrast sagittal T2-weighted MRI of the lumbar spine demonstrating a large cystic tumor at L1-L2 level with involvement of medullary conus and flum terminale (asterisk) (a). Sagittal T1-weighted MRI revealing two additional lesions at $L 3$ level, and $S 1$ segment as the site of primary seeding (arrows) (b). Axial postcontrast T1-weighted MRI depicting separate tumors at L1 (c) and L3 levels (d) (arrows). Postoperative sagittal T2weighted (e) and post-contrast T1-weighted $M R I(f)$ confirming total resection of all the three tumors.

\section{Case 7}

A 33-year-old male presented with sudden urinary retention and no other symptoms or neurological impairment. Preoperative post-contrast sagittal T2weighted MRI of the lumbar spine showed a large cystic tumor at L1-L2 level with involvement of the medullary conus and filum terminale (asterisk) (Fig. 7a), while T1-weighted MRI revealed two additional lesions at L3 level, and S1 segment, which was the site of primary seeding (arrows) (Fig. 7b). Axial post-contrast T1-weighted MRI confirmed the separate tumors at L1 (Fig. 7c) and L3 levels (Fig. 7d) (arrows). The tumor was classified as type IV B MPE (involving the entire medullary conus with cystic compartment). Postoperative sagittal T2-weighted (Fig. 7e) and postcontrast T1-weighted MRI (Fig. 7f) confirmed total resection of all the three tumors. Following surgery, urinary retention resolved entirely, and the patient recovered completely. Further MRI screenings excluded secondary seeding.

\section{Discussion}

We have proposed an original 5-type MPE classification based on tumor location and its correlation with the extent of resection ${ }^{16}$ (Table 1, Fig. 8). Accordingly, extramedullary intradural MPEs incorporating filum terminale only represent type I A, where gross total resection is achievable easily. Type I B stands for extramedullary conus tumors involving lumbar nerve roots together with filum terminale, which are surgically more challenging. Type II represents intramedullary MPEs where conus and filum terminale are involved that could be easily treated by gross total resection. Type III encompasses intramedullary MPEs involving the lower spinal cord, medullary conus and filum, causing the upper lumbar cord enlargement. Type IV A stands for solid or cystic MPEs involving the lower spinal cord, while type IV B represents the entire medullary conus involvement with MPE having a cystic component, and signs of hydromyelia/syringomyelia upon the tumor site, where gross or subtotal resection are management options. Tumors located

Table 1. Classification of spinal cord myxopapillary ependymoma

\begin{tabular}{|l|l|}
\hline Type I A & Filum terminale only \\
\hline Type I B & $\begin{array}{l}\text { Extramedullary conus with lumbar nerve } \\
\text { root and filum }\end{array}$ \\
\hline Type II & Intramedullary conus and filum terminale \\
\hline Type III & Upper lumbar cord enlargement \\
\hline Type IV A & $\begin{array}{l}\text { Lower part of spinal cord and medullary } \\
\text { conus with solid and cystic component }\end{array}$ \\
\hline Type IV B & $\begin{array}{l}\text { Entire medullary conus with cystic } \\
\text { compartment and signs of hydromyelia/ } \\
\text { syringomyelia in the cord upper part }\end{array}$ \\
\hline Type V A & $\begin{array}{l}\text { Outside the lumbar cord } \\
\text { (cervical/thoracic spine) }\end{array}$ \\
\hline Type V B & $\begin{array}{l}\text { Outside the vertebral canal } \\
\text { (intracranial, sacrococcygeal) }\end{array}$ \\
\hline
\end{tabular}



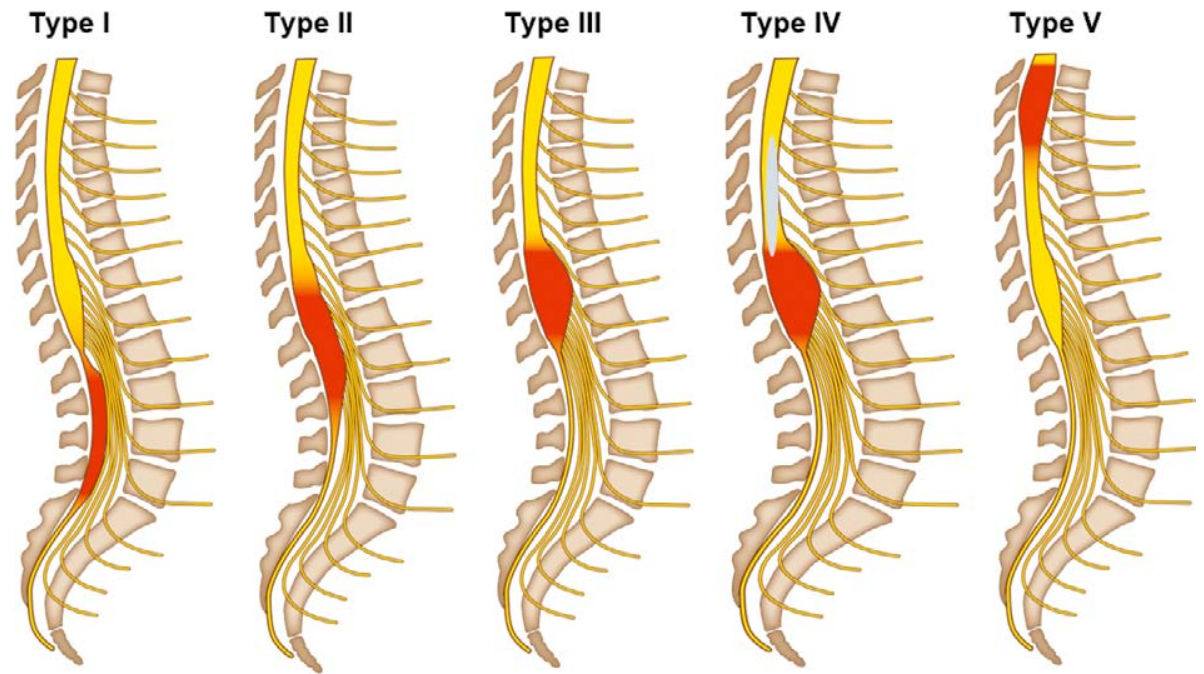

Fig. 8. Schematic drawing of 5-type spinal cord MPE classification.

outside the lumbar cord, but still within the vertebral canal along the thoracic and/or cervical spine represent type V A MPE, whereas those located outside the vertebral canal epitomize type V B MPEs that may be situated at intracranial or sacrococcygeal regions.

Reviewing the literature, we found that the mean patient age at the time of tumor symptomatic occurrence was 36.44 years, and that medullary conus was involved in $28.4 \%$ of cases $^{17}$, which was less consistent with our results where the mean patient age was 47.28 years and the entire medullary conus was involved in four out of seven (57.1\%) patients.

Younger age, preoperative functional capacity, lesser initial neurological deficit, tumor location, size and the extent of resection, as well as adjuvant radiotherapy were identified as significant prognostic factors influencing better outcome $e^{8,13,18,19}$. All the patients from our series had minor or lesser degree neurological deficit on admission, and total surgical tumor resection was possible in all of them.

Long-term outcome is also correlated to the extent of tumor resection, as well as to the integrity of the tumor capsule 7,20 , since larger tumors may perforate the capsule ${ }^{14}$, leading to CSF seeding and dissemination $^{21}$. Hence, an association between capsular damage and tumor relapse was found ${ }^{22}$. Still, surgical morbidity is generally low and postoperative clinical improvement is pretty good, while recurrence rate remains scarce when treatment recommendations and protocols are strictly followed by an experienced neurosur- geon and other medical staff7,23. The same happened with the patients from this series where no surgical morbidity and no tumor relapse or dissemination was observed. Accordingly, Klekamp et al. report that gross total tumor resection was achieved in $77.7 \%$ of their patients ${ }^{7}$, while several studies suggest that it must be combined with high-dose radiotherapy in order to improve the outcome ${ }^{24-26}$, and to avoid recurrence, as well as primary and secondary seeding, which remains under-recognized in adults ${ }^{1,27}$. Although tumor benign histologic features are commonly preserved in case of dissemination ${ }^{28}$, rostral neuro-axial spread mostly affects the thoracic and cervical spine ${ }^{29,30}$. Then, additional resection or irradiation would be endorsed if metastases become symptomatic ${ }^{30}$. There are single case reports describing the benefits of second- and third-line chemotherapy concomitant with radiotherapy after multiple surgeries of recurrent MPE with disseminated metastases ${ }^{31,32}$. However, this was not the case in patients from our series, since all of them recovered well after total tumor resection. Therefore, the need for repeat surgery or adjuvant therapy was not established and no tumor relapse or dissemination was recorded. Nonetheless, one should still remember the possibility of tumor relapse, primary seeding, and drop metastases; one should also consider the entire craniospinal neuroimaging as part of both the preoperative work-up and postoperative follow-up ${ }^{1}$. Therefore, long-term or lifelong MRI surveillance should be advised $^{1,16}$, which is also part of our patient protocol. 
In conclusion, having in mind the small number of patients in this personal case series, as well as its retrospective design, our findings suggest that MPE management based on the proposed 5-type tumor classification is favorable when total surgical resection is performed in carefully selected patients, which is wellsupported by the literature data. Yet, additional studies on a much broader model are obligatory to confirm these results.

\section{Acknowledgment}

We thank Mr. Andrew Gienapp for editing this manuscript.

\section{References}

1. Khan NR, VanLandingham M, O'Brien T, et al. Primary Seeding of Myxopapillary Ependymoma: Different Disease in Adult Population? Case Report and Review of Literature. World Neurosurg. 2017;99:812.e21-.e26. http://dx.doi.org/ 10.1016/j.wneu.2016.12.022.

2. Celli P, Cervoni L, Cantore G. Ependymoma of the filum terminale: treatment and prognostic factors in a series of 28 cases. Acta Neurochir (Wien). 1993;124(2-4):99-103, http://dx.doi. org/10.1007/BF01401130

3. Schiffer $\mathrm{D}$, Chiò A, Giordana MT, et al. Histologic prognostic factors in ependymoma. Childs Nerv Syst. 1991;7(4):177-82, http://dx.doi.org/10.1007/BF00249392

4. Sonneland PR, Scheithauer BW, Onofrio BM. Myxopapillary ependymoma. A clinicopathologic and immunocytochemical study of 77 cases. Cancer. 1985;56(4):883-93, http://dx.doi. org/10.1002/1097-0142(19850815)56:4<883::aid-cncr282056 $0431>3.0 . \mathrm{co} ; 2-6$

5. Banan R, Hartmann C. The new WHO 2016 classification of brain tumors-what neurosurgeons need to know. Acta Neurochir (Wien). 2017;159(3):403-18, http://dx.doi.org/10.1007/ s00701-016-3062-3.

6. Louis DN, Perry A, Reifenberger G, et al. The 2016 World Health Organization Classification of Tumors of the Central Nervous System: a summary. Acta Neuropathol. 2016;131 (6):803-20, http://dx.doi.org/10.1007/s00401-016-1545-1.

7. Klekamp J. Spinal ependymomas. Part 2: Ependymomas of the filum terminale. Neurosurg Focus. 2015;39(2):E7, http:// dx.doi.org/10.3171/2015.5.FOCUS15151.

8. Klekamp J, Samii M. Surgery of Spinal Tumors. New York: Springer; 2007. http://dx.doi.org/10.1007/978-3-540-44715-3

9. Liu T, Yang C, Deng X, et al. Clinical characteristics and surgical outcomes of spinal myxopapillary ependymomas. Neurosurg Rev. 2019, http://dx.doi.org/10.1007/s10143-019-01150-z.

10. Hoving EW, Haitsma E, Oude Ophuis CM, et al. The value of intraoperative neurophysiological monitoring in tethered cord surgery. Childs Nerv Syst. 2011;27(9):1445-52, http://dx.doi. org/10.1007/s00381-011-1471-4.

11. Tobin MK, Geraghty JR, Engelhard HH, et al. Intramedullary spinal cord tumors: a review of current and future treatment strategies. Neurosurg Focus. 2015;39(2):E14, http://dx.doi. org/10.3171/2015.5.FOCUS15158.

12. Fassett DR, Pingree J, Kestle JR. The high incidence of tumor dissemination in myxopapillary ependymoma in pediatric patients. Report of five cases and review of the literature. J Neurosurg. 2005;102(1 Suppl):59-64, http://dx.doi.org/10.3171/ ped.2005.102.1.0059.

13. Weber DC, Wang Y, Miller R, et al. Long-term outcome of patients with spinal myxopapillary ependymoma: treatment results from the MD Anderson Cancer Center and institutions from the Rare Cancer Network. Neuro Oncol. 2015;17(4):58895, http://dx.doi.org/10.1093/neuonc/nou293.

14. Nakamura M, Ishii K, Watanabe K, et al. Long-term surgical outcomes for myxopapillary ependymomas of the cauda equina. Spine (Phila Pa 1976). 2009;34(21):E756-60, http://dx.doi. org/10.1097/BRS.0b013e3181b34d16.

15. McCormick PC. Microsurgical enbloc resection of myxopapillary cauda equina ependymoma. Neurosurg Focus. 2014; 37 Suppl 2:Video 7, http://dx.doi.org/10.3171/2014.V3.FOCUS14272.

16. Omerhodzic I, Pojskic M, Arnautovic K. Myxopapillary Ependymomas. In: Arnautovic K, Ziya G, editors. Spinal Cord Tumors: Springer Verlag; 2019. p. 273-300.

17. Pesce A, Palmieri M, Armocida D, et al. Spinal Myxopapillary Ependymoma: The Sapienza University Experience and Comprehensive Literature Review Concerning the Clinical Course of 1602 Patients. World Neurosurg. 2019;129:245-53, http:// dx.doi.org/10.1016/j.wneu.2019.05.206.

18. Bates JE, Choi G, Milano MT. Myxopapillary ependymoma: a SEER analysis of epidemiology and outcomes. J Neurooncol. 2016;129(2):251-8, http://dx.doi.org/10.1007/s11060016-2167-0.

19. Chang UK, Choe WJ, Chung SK, et al. Surgical outcome and prognostic factors of spinal intramedullary ependymomas in adults. J Neurooncol. 2002;57(2):133-9, http://dx.doi.org/ 10.1023/a:1015789009058

20. Bagley CA, Wilson S, Kothbauer KF, et al. Long term outcomes following surgical resection of myxopapillary ependymomas. Neurosurg Rev. 2009;32(3):321-34; discussion 34, http://dx.doi.org/10.1007/s10143-009-0190-8.

21. Rezai AR, Woo HH, Lee M, et al. Disseminated ependymomas of the central nervous system.J Neurosurg. 1996;85(4):61824, http://dx.doi.org/10.3171/jns.1996.85.4.0618.

22. Abdulaziz M, Mallory GW, Bydon M, et al. Outcomes following myxopapillary ependymoma resection: the importance of capsule integrity. Neurosurg Focus. 2015;39(2):E8, http:// dx.doi.org/10.3171/2015.5.FOCUS15164.

23. Pojskić M, Arnautović KI. Microsurgical Resection of LowGrade Spinal Cord Astrocytoma: 2-Dimensional Operative 
Video. Oper Neurosurg (Hagerstown). 2019;17(3):E107-E8, http://dx.doi.org/10.1093/ons/opy386.

24. Chao ST, Kobayashi T, Benzel E, et al. The role of adjuvant radiation therapy in the treatment of spinal myxopapillary ependymomas. J Neurosurg Spine. 2011;14(1):59-64, http:// dx.doi.org/10.3171/2010.9.SPINE09920.

25. Lee SH, Chung CK, Kim CH, et al. Long-term outcomes of surgical resection with or without adjuvant radiation therapy for treatment of spinal ependymoma: a retrospective multicenter study by the Korea Spinal Oncology Research Group. Neuro Oncol. 2013;15(7):921-9, http://dx.doi.org/10.1093/ neuonc/not038.

26. Pica A, Miller R, Villà S, et al. The results of surgery, with or without radiotherapy, for primary spinal myxopapillary ependymoma: a retrospective study from the rare cancer network. Int J Radiat Oncol Biol Phys. 2009;74(4):1114-20, http:// dx.doi.org/10.1016/j.ijrobp.2008.09.034.

27. De Falco R, Scarano E, Di Celmo D, et al. Concomitant localization of a myxopapillary ependymoma at the middle thoracic part of the spinal cord and at the distal part of the filum terminale. Case report. J Neurosurg Sci. 2008;52(3):87-91.
28. Plans G, Brell M, Cabiol J, et al. Intracranial retrograde dissemination in filum terminale myxopapillary ependymomas. Acta Neurochir (Wien). 2006;148(3):343-6; discussion 6, http://dx.doi.org/10.1007/s00701-005-0693-1.

29. Andoh H, Kawaguchi Y, Seki S, et al. Multi-focal Myxopapillary Ependymoma in the Lumbar and Sacral Regions Requiring Cranio-spinal Radiation Therapy: A Case Report. Asian Spine J. 2011;5(1):68-72, http://dx.doi.org/10.4184/asj.2011. 5.1.68.

30. Kraetzig T, McLaughlin L, Bilsky MH, et al. Metastases of spinal myxopapillary ependymoma: unique characteristics and clinical management. J Neurosurg Spine. 2018;28(2):201-8, http://dx.doi.org/10.3171/2017.5.SPINE161164.

31. Fegerl G, Marosi C. Stabilization of metastatic myxopapillary ependymoma with sorafenib. Rare Tumors. 2012;4(3):e42, http://dx.doi.org/10.4081/rt.2012.e42.

32. Fujiwara Y, Manabe H, Izumi B, et al. Remarkable efficacy of temozolomide for relapsed spinal myxopapillary ependymoma with multiple recurrence and cerebrospinal dissemination: a case report and literature review. Eur Spine J. 2017, http://dx. doi.org/10.1007/s00586-017-5413-z.

Sažetak

\section{MIKSOPAPILARNI EPENDIMOM KRALJEŽNIČNE MOŽDINE U ODRASLIH: PRIKAZ OSOBNE SERIJE I PREGLED LITERATURE}

\section{Omerhodžić, M. Pojskić, K Rotim, B. Splavski, L Rasulići K. Arnautovic}

Miksopapilarni ependimomi (MPE) kralježnične moždine sporo su rastući, dobroćudni tumori najčešce zastupljeni u odraslih u dobi između 30 i 50 godina života. Nastaju iz ependima filuma terminale, a pretežito su smješteni u području medularnoga konusa i kaude. Kirurško uklanjanje tumora u cijelosti preporučena je metoda liječenja, dok u bolesnika u kojih to nije moguće učiniti u obzir dolazi subtotalna resekcija nakon koje je potrebno zračenje. Potpuno uklanjanje tumora uz očuvanje cjelovitosti tumorske kapsule postiže se jednostavnom resekcijom filuma terminale iznad i ispod tumorske mase, što može dovesti do izlječenja. Unatoč tomu, tumorska diseminacija uzduž neuralne osi može se javiti u oko $30 \%$ slučajeva. U ovom radu predlažemo originalnu klasifikaciju MPE koja prosuđuje smještaj tumora i obujam tumorske resekcije, a temeljena je na osobnoj seriji operiranih bolesnika. Također raspravljamo o kirurškoj tehnici, o mogućnostima recidiva i širenja ovakvih tumora, kao i o oblicima pomoćnog liječenja, koristeći se pregledom literature. Zaključujemo kako naši rezultati zagovaraju kirurško liječenje temeljeno na predloženoj originalnoj tumorskoj klasifikaciji, koje može biti uspješno u pažljivo odabranih bolesnika u kojih je tumor uklonjen u cijelosti. Naknadna istraživanja na znatno većem uzorku potrebna su za potvrdu naših rezultata.

Ključne riječi: Miksopapilarni ependimom; Potpuna resekcija tumora; Kirurška tehnika; Klasifikacija tumora 